\title{
Attitudes of Pediatricians Regarding Prevention and Treatment of Vitamin D Deficiency
}

\author{
Gülcan Seymen Karabulut1, Şükrü Hatun1, Aysun Bideci2, Enver Hasanoğlu33 \\ ${ }^{1}$ Kocaeli University Faculty of Medicine, Department of Pediatric Endocrinology, Kocaeli, Turkey \\ ${ }^{2}$ Gazi University Faculty of Medicine, Department of Pediatric Endocrinology, Ankara, Turkey \\ ${ }^{3}$ National Pediatrics Association, Ankara, Turkey
}

\section{ABSTRACT}

To determine the adherence of pediatricians to the nationwide 'Vitamin D Prophylaxis Program' and to evaluate their attitudes about vitamin D intake. The study was conducted using the Turkish National Pediatrics Association network. The pediatricians were asked to respond to an online questionnaire that included five questions on 'What dose of vitamin D they recommend for supplementation?', 'At what age they start vitamin D supplementation?', 'Supplementation method', 'Clichés and truths about vitamin D', and 'High-dose vitamin D therapy indications'. Responses of 167 pediatricians were evaluated in this study. $75.5 \%$ of pediatricians indicated that they recommended vitamin $D$ supplementation in a daily dose of 400 IU. $47.1 \%$ started vitamin D supplementation by the end of the $2^{\text {nd }}$ week. $7.83 \%$ of pediatricians suggested doubling the daily dose of vitamin D supplementation in infants with delayed tooth eruption, 19.9\% suggested immediate cessation of vitamin D supplementation in infants with small anterior fontanels. This study showed that the majority of the pediatricians still prescribe vitamin $\mathrm{D}$ prophylaxis late, recommend high doses of vitamin $D$ in cases of delayed tooth eruption, and think that low serum 25-hydroxy vitamin $\mathrm{D}$ level regardless of alkaline or phosphatase parathyroid hormone measurement is an indication for high-dose vitamin $D$ (stoss) therapy. These results suggest a need for new training programs focusing on vitamin $D$ supplementation.

Keywords: Vitamin D deficiency, prevention, pediatrician attitudes

Conflict of interest: None declared

Received: 08.02.2016

Accepted: 28.03.2016

\section{Introduction}

While there is an increased awareness on the critical role of vitamin $D$ on health, vitamin D deficiency is still an important health problem due to the influence of social, cultural, and geographic factors (1). Symptomatic vitamin D deficiency leads to morbidities including congenital and infantile rickets, hypocalcemic

\footnotetext{
Address for Correspondence

Şükrü Hatun MD, Kocaeli University Faculty of Medicine, Department of Pediatric Endocrinology, Kocaeli, Turkey

E-mail:sukruhatun@gmail.com

OJournal of Clinical Research in Pediatric Endocrinology, Published by Galenos Publishing
} 
convulsions, dilated cardiomyopathy, skeletal myopathy, and osteomalacia from fetal life to adulthood. It may even lead to death. All these conditions are reversible and also preventable. Therefore, it is essential to clarify the responsibilities of families, physicians, and healthcare system in preventing vitamin $D$ deficiency and to establish vitamin $D$ supplementation as a public health priority similar to vaccination (2).

A nationwide vitamin $D$ prophylaxis program that included free distribution of vitamin $D$ drops to all newborns and infants (0-12 months) attending primary health centers throughout the country was initiated in 2005 in Turkey (3). However, it has been reported that physician attitude for vitamin $D$ supplementation is not always in compliance with guidelines and also that some parents are unwilling to keep up with recommendations $(4,5,6)$.

This study aimed to determine the adherence of pediatricians to the guidelines of the program and to evaluate their fundamental attitudes about vitamin D deficiency and vitamin D supplementation.

\section{Methods}

The study was conducted making use of the Turkish National Pediatrics Association Network. The questionnaire was sent to 1800 pediatricians. The pediatricians filled out an online questionnaire regarding their policy on vitamin $D$ supplementation.

The questionnaire consisted of 5 questions. The first part three questions were on vitamin $D$ supplementation practices:

What daily dose of vitamin $D$ supplementation do you recommend? $1200 \mathrm{IU}, 400 \mathrm{IU}, 600 \mathrm{IU}, 800 \mathrm{IU}$.

At what age do you recommend to start vitamin supplementation? Soon after birth, at the end of the 1st week, at the end of the $2^{\text {nd }}$ week, at the end of the $3^{\text {rd }}$ week, after age one month.

Which method do you prefer for vitamin D supplementation? Three drops orally once daily (400 IU/day), eight drops orally once daily (1000 IU/day), one vial (300.000 IU) orally once a month, one vial (300.000 IU) orally every two months, one vial (300.000 IU) intramuscularly every two months.

We also asked whether their practices were influenced by some common non-scientific beliefs.

Clichés and truths about vitamin D intake (giving double dose of daily vitamin $D$ prophylaxis in infants with delayed tooth eruption, abstaining from vitamin D supplementation in infants with small anterior fontanelles, giving extra doses of vitamin $D$ to infants with delayed walking and/or leg bowing).

The last question queried whether they followed the undermentioned indications for high-dose vitamin D therapy (stoss therapy) in their clinical practice.

High-dose vitamin D therapy indications for all newborns and infants consist of a 25-hydroxy vitamin D [25(OH)D] level $<15 \mathrm{ng} / \mathrm{mL}$, an elevated serum alkaline phosphatase levels in addition to a serum 25(OH)D level of $<15 \mathrm{ng} / \mathrm{mL}$, and presence of craniotabes in addition to a serum 25(OH)D level $<15 \mathrm{ng} / \mathrm{mL}$.

\section{Results}

A total of 167 pediatricians completed the questionnaire. $75.5 \%$ of them indicated that they routinely recommended daily vitamin D prophylaxis in a dose as 400 IU. $10.2 \%$ of respondents recommended vitamin $D$ prophylaxis in a daily dose of $800 \mathrm{IU}$. The remainder of the responders stated they recommended daily doses of $1200 \mathrm{IU}$ and $600 \mathrm{IU}$. $28.7 \%$ of respondents recommended beginning vitamin $D$ prophylaxis soon after birth and $47.3 \%$ recommended beginning by the end of the 2 nd week. $86.2 \%$ of respondents recommended daily 3 drops for vitamin D prophylaxis, while $11.38 \%$ recommended daily 8 drops and $1.2 \%$ administration of oral $300.000 \mathrm{IU}$ every 2 months.

$7.8 \%$ of respondents suggested doubling the daily dose of vitamin D prophylaxis in infants with delayed tooth eruption, $19.9 \%$ suggested immediate cessation of vitamin D in infants with small anterior fontanelle, while $2.4 \%$ suggested giving 300.000 IU of vitamin D every two months to infants with delayed walking and $16.9 \%$ suggested giving $300.000 \mathrm{IU}$ of vitamin $\mathrm{D}$ to infants with leg bowing (Table 1).

\section{Discussion}

The nationwide vitamin D prophylaxis program of the Turkish Ministry of Health successfully reduced the prevalence of rickets in Turkey from 6\% in 1998 to $0.1 \%$ in 2008 in children under 3 years of age (3). This program is closely controlled by the Turkish Ministry of Health using a 'performance assessment system' that monitors primary care doctors' practices and rewards those who are compliant with the nationwide vitamin D prophylaxis program. In this program, the recommended daily vitamin $\mathrm{D}$ dose is $400 \mathrm{IU}$, which is compatible with the "Institute of Medicine (IOM) Committee's http://www. nationalacademies.org/hmd/ 2011 Report on Dietary Reference Intakes for Calcium and Vitamin D". This dose was chosen also because a daily $400 \mathrm{U}$ supplementation of vitamin $D$ was shown to be adequate to provide a serum 25(OH)D level $>15$

\begin{tabular}{|l|l|}
\hline \multicolumn{2}{|l|}{$\begin{array}{l}\text { Table 1. For which of the following groups of infants is high-dose } \\
\text { vitamin D therapy most appropriate? }\end{array}$} \\
\hline Options & $\begin{array}{l}\text { Percentage of } \\
\text { responders (\%) }\end{array}$ \\
\hline $\begin{array}{l}\text { Newborns and infants with serum 25-hyroxy } \\
\text { vitamin D levels } \\
<15 \mathrm{ng} / \mathrm{mL}\end{array}$ & 34.73 \\
\hline $\begin{array}{l}\text { Newborns and infants with serum 25-hyroxy } \\
\text { vitamin D levels } \\
<15 \mathrm{ng} / \mathrm{mL} \text { and elevated serum alkaline } \\
\text { phosphatase levels }\end{array}$ & 34.73 \\
\hline $\begin{array}{l}\text { Newborns and infants with serum 25-hyroxy } \\
\text { vitamin D levels } \\
<15 \mathrm{ng} / \mathrm{mL} \text { and also craniotabes }\end{array}$ & 30.54 \\
\hline
\end{tabular}


$\mathrm{ng} / \mathrm{mL}$ in $>90 \%$ of all infants $(7,8)$. In a large scaled survey study by the Ministry of Health to evaluate the success of the nationwide program, it was shown that of 2504 infants aged between 6 and 17 months, serum 25(OH)D level was $>15 \mathrm{ng} /$ $\mathrm{mL}$ in $73.6 \%$ (9). This is consistent with our survey findings that a similar percentage of pediatricians adhere to recommended vitamin D supplementation of the nationwide program. The survey also showed that a great majority of pediatricians preferred giving vitamin D supplementation daily and orally.

While this was encouraging, more than half of the pediatricians who responded to our questionnaire recommend to start supplementation later than the age recommended by the Ministry of Health. We believe this finding is mostly due to the misconception among pediatricians that the maternal transfer of vitamin $D$ in utero would protect the infants against vitamin D deficiency in the first 3 weeks of life (10). However, because of the high incidence of maternal vitamin $D$ deficiency, the American Academy of Pediatrics determined the beginning time of vitamin $D$ supplementation as the first few days of life $(6,11,12)$. We believe that a new information campaign is needed to change the physicians' attitudes for the starting age of vitamin D prophylaxis.

The results of our study reveal that non-scientific beliefs may influence clinical practice. $20 \%$ of the physicians thought that vitamin $\mathrm{D}$ supplementation should be stopped in babies with small anterior fontanels. We suppose that this belief is because of a misconception that if vitamin D deficiency can delay anterior fontanel closure, an early closure of fontanel should indicate vitamin D excess. Another stereotyped approach is erroneously considering bowing in infants automatically as a sign of vitamin $D$ deficiency and prescribing high doses of vitamin $D$ without additional findings though it may be due to other causes (physiological, skeletal dysplasia, or hypophosphatemic rickets). Similarly, $10 \%$ of pediatricians have stated that high-dose vitamin D treatment will accelerate tooth eruption and walking. This is consistent with a common belief among the parents.

Another interesting finding is that most pediatricians routinely analyze serum $25(\mathrm{OH}) \mathrm{D}$ and prescribe high doses of vitamin $D$ (stoss therapy) without assessing the clinical symptoms and/or other biochemical and radiological parameters. We believe this attitude is due to the widely publicized extraskeletal effects of vitamin D (13). However, recently, treatment of vitamin $D$ deficiency rickets has been revised and "stoss" or "single-dose" therapy dosage reduced to 50000 units for the first year of life (14). It is also important to note that in Turkey, 300.000 IU vitamin D vials are available without prescription. The pediatricians' attitude as well as the common belief among the parents that high-dose vitamin $D$ should be given to those children with delayed teething and/ or walking, have led to a possible increase in Turkey of cases of vitamin $D$ intoxication $(15,16)$. In order to prevent vitamin
D intoxication, the pediatricians need to be educated on this matter and over-the-counter sale of high-dose vitamin D preparations should be forbidden.

In conclusion, despite significant progress in the prevention and treatment of vitamin D deficiency in Turkey, some pediatricians still have incorrect attitudes such as starting vitamin D supplementation late, using high doses of vitamin D without a real indication, and accepting low serum $25(\mathrm{OH})$ $D$ levels sufficient to begin high-dose vitamin $D$ therapy. We believe there is a need for a new reinforcing education program among the pediatricians.

\section{Ethics}

Peer-review: Externally peer-reviewed.

\section{Authorship Contributions}

Concept: Şükrü Hatun, Design: Gülcan Seymen Karabulut, Şükrü Hatun, Data Collection or Processing: Enver Hasanoğlu, Analysis or Interpretation: Şükrü Hatun, Aysun Bideci, Literature Search: Şükrü Hatun, Writing: Gülcan Seymen Karabulut, Şükrü Hatun.

Financial Disclosure: The authors declared that this study received no financial support.

\section{References}

1. Elder CJ, Bishop NJ. Rickets. Lancet 2014;383:1665-1676. Epub 2014 Jan 10

2. Högler W. Complications of vitamin D deficiency from the foetus to the infant: One cause, one prevention, but who's responsibility? Best Pract Res Clin Endocrinol Metab 2015;29:385-398. Epub 2015 Mar

3. Hatun Ş, Ozkan B, Bereket A. Vitamin D deficiency and prevention: Turkish experience. Acta Paediatr 2011;100:11951199. Epub 2011 Jul 4

4. Davenport ML, Uçkun A, Calikoglu AS. Pediatrician patterns of prescribing vitamin supplementation for infants: do they contribute to rickets? Pediatrics 2004;113:179-180.

5. Toprak Gedikbaşı D, Hatun Ş. D vitamin yetersizligi ve D vitamin destegi konusunda pratisyen hekimlerin tutumları. Sted 2004;13:16-18

6. Taylor JA, Geyer LJ, Feldman KW. Use of supplement I vitamin D among infants breastfed for prolonged periods. Pediatrics 2010;125:105-111. Epub 2009 Nov 30

7. Institute of Medicine (US) Committee to Review. Dietary reference intakes for calcium and vitamin D. In: Ross AC, Taylor CL, Ann L Yaktine, Del Valle HB (eds). Washington, DC: The National Academies Press, 2011; 260-262.

8. Mutlu GY, Kusdal Y, Ozsu E, Cizmecioglu FM, Hatun S. Prevention of Vitamin D deficiency in infancy: daily $400 \mathrm{IU}$ vitamin D is sufficient. Int J Pediatr Endocrinol 201;2011:4. Epub 2011 Jun 28

9. Türkiye'de 6-17 Aylık Çocuklarda ve Annelerinde Hemoglobin Ferritin D -Vitamini Düzeyi ve Demir Eksikliği Anemisi Durum BelirlemeYürütülen Programların Değerlendirilmesi Araştırması. Ankara, Sağlık Bakanlığı Yayınları, 2011:81-86. 
Seymen Karabulut G et al.

Attitudes of Pediatricians about Vitamin D

10. Gartner LM, Greer FR; Section on Breastfeeding and Committee on Nutrition. American Academy of Pediatrics. Prevention of rickets and vitamin D deficiency: new guidelines for vitamin D intake. Pediatrics 2003;111:908-910.

11. Misra M, Pacaud D, Petryk A, Collett-Solberg PF, Kappy M; Drug and Therapeutics Committee of the Lawson Wilkins Pediatric Endocrine Society. Vitamin D deficiency in children and its management: review of current knowledge and recommendations. Pediatrics 2008;122:398-417.

12. Thandrayen K, Pettifor JM. Maternal Vitamin D status: implications for the development of infantile nutritional rickets. Endocrinol Metab Clin North Am 2010;39:303-320.

13. Rosen CJ, Abrams SA, Aloia JF, Brannon PM, Clinton SK, Durazo-Arvizu RA, Gallagher JC, Gallo RL, Jones G, Kovacs CS, Manson JE, Mayne ST, Ross AC, Shapses SA, Taylor CL. IOM committee members respond to Endocrine Society vitamin D guideline. J Clin Endocrinol Metab 2012;97:11461152. Epub 2012 Mar 22

14. Munns CF, Shaw N, Kiely M, Specker BL, Thacher TD, Ozono K, Michigami T, Tiosano D, Mughal MZ, Mäkitie O, Ramos-Abad L, Ward L, DiMeglio LA, Atapattu N, Cassinelli $H$, Braegger $C$, Pettifor JM, Seth $A$, Idris HW, Bhatia $V_{\text {, }}$ Fu J,Goldberg G, Sävendahl L, Khadgawat R, Pludowski P, Maddock J, Hyppönen E, Oduwole A, Frew E, Aguiar M, Tulchinsky T, Butler G, Högler W. Global Consensus Recommendations on Prevention and Management of Nutritional Rickets. J Clin Endocrinol Metab 2016;101:394415. Epub 2016 Jan 8

15. Döneray H, Özkan B, Özkan A, Koşan C, Orbak Z, Karakelleoğlu C. The clinical and laboratory characteristics of vitamin D intoxication in children. Turk J Med Sci 2009;39:1-4.

16. Ozkan B, Hatun S, Bereket A. Vitamin D intoxication. Turk J Pediatr 2012;54:93-98. 